\title{
Slivers of Hope: Women in Dystopian Trilogy
}

\author{
Josephine May Grace A. Famoso \\ English Department \\ Mindanao State University-Iligan Institute of Technology \\ Philippines \\ famosojosephine@gmail.com
}

Citation: Famoso, J. M. G. A. (2021). Slivers of hope: Women in dystopian trilogy. Notion: Journal of Linguistics, Literature, and Culture, Vol 3(2), p. 81-91. http://doi.org/notion.v3i2.4809

\section{Article Info}

Article History

- Article Received September $4^{\text {th }}, 2021$

- Article Accepted

October $27^{\text {th }}, 2021$

\section{Keywords}

Dystopia

Feminism

Hope

Revolution

\section{ABSTRACT}

This paper explores the struggles, goals, and motivations of the women characters in The Hunger Games Trilogy. In detail, the study employs Elaine Showalter's Feminist theory to reveal the women characters' categories in terms of three stages: feminine, feminist and female. In the study, some of the women characters living in the dehumanized society of Panem have attained the last stage of feminism which is the female stage. However, other women characters are not able to fulfill their goals. Still, due to the women characters' demand to change the system, they start an uprising. For example, the main character, Katniss Everdeen, contributes to the collapse of the ruling government in power as she accepts being the Mockingjay, the symbol of revolution. Another woman character to exemplify such a noble act is Johanna Mason who becomes part of the rebellion and survives the war against the unjust ruling of the Capitol. These women characters are slivers of light amidst the chaos. In conclusion, it is discovered that women characters play pivotal roles in society. This suggests that women characters recognize their power to accelerate societal advancement. For this dystopian trilogy, in particular, women become symbols of hope. 


\section{Famoso, Josephin May Grace A. Slivers of Hope: Women in Dystopian Trilogy}

\section{INTRODUCTION}

Literature is a reflection of its milieu. It is considered as one of the creative criticisms of society. In the past, women are shown as delicate, submissive counterparts for men who are leaders. However, futuristic write-ups attempt to change the narrative participated by women. This becomes the new image women portray in literature. Strong women characters are now role models to young girls and boys in the unfolding of a new time.

Back in the day, society dictates the role women play in literary pieces. Many writers portray women characters as a one image individual. This characterization in literature limits women in aspects such as opportunity, merit, and so on. Yet, in reality, many contemporary world leaders are female, challenging the stereotypes and breaking barriers.

In the international scene, the Prime Minister of New Zealand and new mom, Jacinda Ardern, was lauded for her empathetic nonetheless scientificbased kind of leadership in the initial height of the Covid-19 crisis. In the words of Kolb[11], throughout the pandemic, rather than evoke Arden's power or political position, she relied consistently on the available scientific data and medical advisors to inform her decisions. Clearly, this serves as a case of an exemplary adaptive leadership as achieving a balance of reason and compassion is no mean feat, but it is one worth striving for.

Another exemplary case of a woman that embodies many things is Taiwan's first unmarried President, Tsai Ing-Wen. It's her firm resistance of Taiwan's independence in the face of continuous pressure from China that has made her a hero to her people[9]. Tsai has forged her own path, making her one of the most remarkable leaders.

In the Philippines, a number of women have made changes possible. One of them is the young female activist, Ana Patricia Non, who set up a community pantry to feed the poor that inspired other Filipinos to do the same amidst the Covid-19 pandemic. The initiative became a nationwide trend and does not discriminate against gender, class, affiliation, religion, or anything else[1].

Remarkably, contemporary literature depict women characters as well-rounded and capable of defiance that changed their world. In literature, The Scarlet Letter by a famous novelist named Nathaniel Hawthorne[12] is a tragic narrative of a lady who experienced shame and cruelty from the hands of the Puritan society. Hence, the use of Feminism in this novel is inevitable.

Feminism is about gender differences imposed by a certain society. Feminism was certainly not in existence in the setting of Hawthorne's novel, nor was it supported in 1850 when The Scarlet Letter was published. Nevertheless, Hawthorne's outset of progression for women's place in society is certainly evident in the thinking of his main character, Hester Prynne, who evinces cultural feminism, which attempts to heighten respect for what is traditionally considered women's work while focusing on building women's culture.

To be able to insert feminism in appreciating this famous novel one must first look at the extent to which the representation of women in the literary piece reflect the place and time the work was written[3]. Second, the roles of both men and women in the work must be taken into consideration, their relationship should be determined. For example, in the Hunger Games the male main character, Peeta, disrupts the gendered dichotomy of virtue. He fits the feminine model of virtue in the trilogy[7]. Another example is how women are seen as possessing either too much or too little power in India. Indian femininity employed these two standard tropes only[10]. Third and last, the feminist critic should research the author's life to find facts that relate to the presentation of men and women in the work[18]. With all these guide in using Feminism as an approach it will be easier to critic a certain novel such as The Scarlet Letter. As for literature by and about women, it will all boil down to three major phases of development. The three stages are Feminine, Feminist, and Female. 
According to a study conducted by Simmons[17], the elements of The Hunger Games trilogy relate to violent acts in our world. Violence toward women and children is not fiction and that the readers can play a role in its abolishment, just like Katniss, through appropriate social actions. Issues like world famine, child labor, and sexual exploitation that appear in both the fictional series and our world are pressing matters. And due to the popularity of The Hunger Games, it can be used as a tool for social responsibility. Similarly, Simmons expands on the idea of using literature as a call for action.

The Hunger Games trilogy challenges oldfashioned models of femininity as well. Even as it romanticizes its teenage heroine, the trilogy embarks on challenging gender norms. In an argument made by Oliver[14], she pointed out that Katniss' ambivalent desires and ambiguous gender identity open up possibilities for girls beyond the traditional patriarchal constraints of wife and mother. A feminist aesthetics of ambiguity presents and represents multivalent meanings for femininity, girlhood, and womanhood that allow girls to imagine futures for themselves beyond those traditionally circumscribed by the roles of lover, wife and mother within patriarchal culture. According to Nehere[13], the type of feminism that is bound to change the social structure for equality is radical feminism. This is seen in the trilogy, The Hunger Games by Suzanne Collins.

The objective of this study is to reveal the women characters' categories in terms of three stages: feminine, feminist and female. As well as determine the women characters' struggles and unveil their goals and motivations.

\section{METHODOLOGY}

The study used a qualitative descriptive method by employing Elaine Showalter's theory of Feminism in The Hunger Games Trilogy by Suzanne Collins. The novels are The Hunger Games (2008)[4], Catching Fire (2009)[5], and Mockingjay (2010)[6] respectively. The series show women characters with diverse characterizations. The paper classified these women characters based on three (3) stages; Feminine, Feminist, and Female. Moreover, the struggles, goals, and motivations of the main character Katniss Everdeen and other minor characters, Primrose, Rue, and Johanna were revealed.

\section{RESULT AND DISCUSSION}

The stages of Feminism according to Elaine Showalter are the Feminine Stage, the Feminist, and Female stage.

\section{Feminine Stage}

Katniss Everdeen is the female tribute of District 12 for the $74^{\text {th }}$ Hunger Games. She volunteers for the Hunger Games when her sister is picked from the reaping. As a resident of one of the districts in Panem, Katniss and other children ages twelve to eighteen are subject for the public reaping under the Treaty of Treason made for the twelve districts against the Capitol during the Dark days. The Public Reaping shows the first sign of Katniss' character being submissive or feminine.

"Taking the kids from our districts, forcing them to kill one another while we watch - this is the Capitol's way of reminding us how totally we are at their mercy." Hunger Games, p. 19.

When Katniss won the $74^{\text {th }}$ Hunger Games, she never escaped the horror of the games. President Snow visits her to gain control over her. He persuades her to act according to his plan.

\section{"II know. I will. I'll convince everyone in the districts that I wasn't defying the capitol, that I was crasy in love," I say. President Snow rises and daps his puffy lips with a napkin. "Aim higher in case you fall short." "What do you mean? How can I aim higher?" I ask. "Convince me" he says. He drops the napkin and retrieves his book. I don't watch him as he heads for the door, so I flinch when he whispers in my ear, "by the way, I know about the kiss." Then the door clicks shut bebind him."”'-Catching Fire, p. 29.}

This proves that President Snow manipulates Katniss. She gives in for fear of her family and friends suffering the consequences. In the $75^{\text {th }}$ Hunger Games, which is the Third Quarter Quell, a special announcement is made by President Snow: 
"On the seventy-fifth anniversary, as a reminder to the rebels that even the strongest among them cannot overcome the power of the Capitol, the male and female tributes will be reaped from their existing pool of victors." - Catching Fire, p. 172.

Since Katniss is the only living female victor of District 12 , she is automatically one of the tributes for the games. In the last novel, Mockingjay, Katniss has nightmares. She decides not to participate and accept the offer to become the symbol of rebellion. Katniss is scared about the upcoming war and the threat given by President Snow of killing the people she loves.

Primrose Everdeen is the young sister of Katniss and is only twelve years old when introduced in the trilogy. Katniss describes her "face is as fresh as a raindrop, as lovely as the primrose for which she was named." -Hunger Games, p. 4. Primrose is obliged to attend the public reaping. This means that this is her feminine stage because she has no choice but to follow the Treaty of Treason that the government imposed as a sanction for the districts.

"Prim is in my first reaping outfit, a skirt and ruffled blouse. It's a bit big on her, but my mother has made it stay with pins. Even so, she's having trouble keeping the blouse tucked in at the back." The Hunger Games, p. 15.

At the start of the novel, Primrose always has nightmares of being chosen as tribute for the $74^{\text {th }}$ Hunger Games. When Primrose and her family arrive in the square where the drawing of names for the next tribute is held, Primrose's premonition comes true. But her sister, Katniss, volunteers for the spot.

Rue is introduced in the first book, The Hunger Games. She is the female tribute from district 11. She is only twelve years old when she is chosen for the games. Rue is the youngest among the tributes during the $74^{\text {th }}$ Hunger Games. This is an indication that Rue has no way of defying the Capitol. Rue's feminine stage is also seen in her life before she is reaped for the games. Rue shares to Katniss the suffering they had in their district. Even the district that specializes in agriculture is hungry.
"I'd have thought that in District 11, you'd have a bit more to eat than us. You know, since you grow the food," I say. Rue's eyes widen. "Oh no, we're not allowed to eat the crops." "They arrest you or something?" I ask. "They whip you and make everyone else watch," says Rue. "The mayor's very strict about it." -The Hunger Games, p. 200.

Rue, being young and passive, cannot do anything about the starvation brought by the austerity of the authority. All she can do is watch as the government steal the crop they cultivated.

Johanna Mason is introduced in the second installment of the trilogy, Catching Fire. She is a victor from the previous games. She is from District 7 which is known for lumbers. Her name is mentioned in the first book, The Hunger Games, in which she is described.

"This worked very well for a girl, Johanna Mason, from District 7 a few years back. She seemed like such a sniveling, cowardly fool that no one bothered about her until there were only a handful of contestants left. I turned out she could kills viciously. Pretty clever the way she played it." -The Hunger Games, p. 41.

When Johanna Mason won, she received prizes from the Capitol. Johanna also thought that after winning the games, she will live in peace with her winnings, but when the $3^{\text {rd }}$ Quarter Quell is announced, like Katniss, she is the only living female tribute of their district that is why she is automatically a participant for the games. Therefore, her compliance to this rule is her feminine stage.

\section{Feminist Stage}

Katniss Everdeen. Rue's death gives Katniss a boost to revolt against the Capitol and its treaty that gives them the Hunger Games. She remembers her friend, Gale, who rants against the Capitol's unjust ruling.

"Gale's voice is in my head. His ravings against the Capitol is no longer pointless, no longer to be ignored. Rue's death has forced me to confront my ownfury against the cruelty, the injustice they inflict upon us." -The Hunger Games, p. 233. 
In the $74^{\text {th }}$ Hunger Games, the Game Makers makes an interesting twist in the rules that "both of the tributes from the same district will be declared winners if they are the last to alive." Katniss then looks for Peeta to save him. At the last day of the Games when Katniss and Peeta are the last tributes to survive and are the supposed winners, the rule is eventually changed. It is again set that only one tribute may win the Games. In order to save the both of them, Katniss decides to pretend to poison themselves so no tribute will rise as a winner. This makes the Game Makers declare both of them as victors.

\section{"'I spread out my fingers, and the dark berries glistened in the sun. I give Peeta's hand one last squeeze as a signal, as a goodbye, and we begin counting. "One." Maybe I'm wrong. "Two." Maybe they don't care if we both die. "Three." It's too late to change my mind. I lift my hand to my mouth. Taking one last look at the world. The berries have just passed my lips when the trumpets begin to blare-The Hunger Games, p. 339.}

This action shows Katniss' first attempt at going against the rules of the government. Her feminist stage involves a risk to defy the government administering the Games.

In Catching Fire, during the last day of the $75^{\text {th }}$ Hunger Games, Katniss remembers Haymitch's final advice "you must remember who the real enemy is." Then Katniss plans to escape the arena.

\section{"I rise turning to the force field, fully revealing myself but no longer caring. Only caring about where I should direct the tip, where Beete would have driven the knife if he had been able to choose. My bow tilts up at the wavering square, the flaw, the... what did he call it that day? The chink in the armor. I let the arrow fly, see it hit the mark and vanish, pulling the thread of gold behind it." - Catching Fire, p. 378.}

Katniss shoots the arrow to the chink with wire tied up at the tip to let the electricity flow. It destroys the arena making some of the tributes escape the Games. This is the second time Katniss demonstrates an act of revolution against the Games and the ruling of the Capitol. She thinks that the real enemy is the Capitol so she destroys the arena for everyone to escape the unjust government and its punishment to the districts. This signals the beginning of her activism.

Primrose Everdeen. In the third novel, Mockingjay, Primrose helps at the hospital in District 13. She becomes a volunteer to aid the injured people during the revolution. This is where Katniss witnesses her death because of an explosion. Nonetheless, Primrose helps in the revolution by caring for the people in the districts.

"Then I am pushing through the crowd, just as I did before. Trying to shout her name above the roar. I'm almost there. Almost to the barricade, when I think she hears me. Because for just a moment, she catches sight of me, her lips form my name. And that's when the parachutes go off." -Mockingjay, p. 347.

Rue. She is a clever player in the Games. Instead of killing the enemies, Rue plans to leave the others famished. She refuses to join the Game and hides. This refusal is an act of going against the rules, therefore showing protest (feminist stage). This is an indication that her rebellion is implied.

Johanna Mason. Before the $75^{\text {th }}$ Hunger Games and the $3^{\text {rd }}$ Quarter Quell begins, a group of rebel plans to help and secure Katniss to be their Mockingjay, the symbol for the rebellion. Johanna is one of the tributes who will protect her from the Career tributes who hunt them to will the games. She saves Wiress and Beetee because Katniss wants them as her allies.

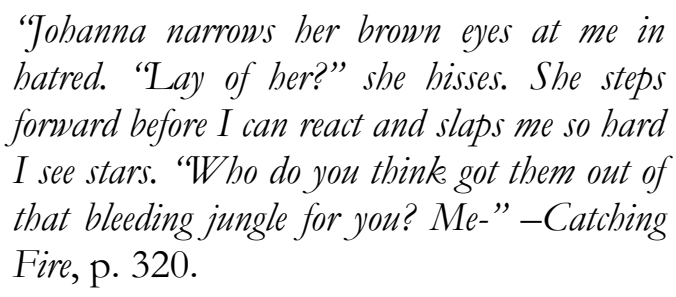

This is clearly an act of rebellion as Johanna disagrees with the system. She loathes the Hunger Games as one of the entertainments of the Capitol.

\section{Female Stage}

Katniss Everdeen. In the trilogy, Katniss achieves freedom by accepting her role as the Mockingjay. After the first Games, she always has 


\section{Famoso, Josephin May Grace A. Slivers of Hope: Women in Dystopian Trilogy}

nightmares and hallucinations about being killed inside the arena.

"In my nightmare, I am dressed in the silk bridal gown, but it's torn and muddy. The long sleeves keep getting caught on thorns and branches as I run throught the woods. The pack of mutation tributes draws closer and closer until it overcomes me with hot breath and dripping fangs and I scream myself awake." -Catching Fire, p. 167.

Katniss has accepted her role fully as the forerunner and symbol of the revolution. She understands her worth by believing that she can free herself and the districts from their nightmarish situation. Katniss rediscovered her existence as something that is vital in helping the society. This practice is seen in the study by Rigaud[15]. Katniss' character primarily shows that a woman can be many other things; she can play many roles and she can, if she wanted to, change the world. Table 1 below displays the women characters and their stages of Feminism.

\begin{tabular}{cccc}
\hline Characters & \multicolumn{3}{c}{ Stages } \\
\hline & Feminine & Feminist & Female \\
\hline Katniss Everdeen & $\mathrm{V}$ & $\mathrm{V}$ & $\mathrm{V}$ \\
\hline Primrose Everdeen & $\mathrm{V}$ & $\mathrm{V}$ & $\mathrm{X}$ \\
\hline Rue & $\mathrm{V}$ & $\mathrm{X}$ & $\mathrm{X}$ \\
\hline Johanna Mason & $\mathrm{V}$ & $\mathrm{V}$ & $\mathrm{X}$
\end{tabular}

Table 1. Feminine, Feminist, and Female Stages

In summary, the stages of feminism according to Elaine Showalter are not achieved by all the female characters being studied. Among the four female characters only Katniss is able to complete the stages. The other two, Primrose and Johanna, wrap up until the feminist stage. And Rue remained in the feminine stage.

Therefore, the female characters in the series are motivators to attaining change for the citizens of Panem. Despite the hindrances of their sex as looked upon by society, they are able to make an impact and changed the status quo.

\section{Struggles}

\section{Hunger Games}

The Hunger Games has been celebrated by people from the Capitol but not by everyone in Panem. The Games start with the Reaping. Every district has to offer two tributes; one female and one male representative. The districts are subjected to this power as punishment ever since the rebellion against the Capitol. The collapsed of the first rebellion is aptly called the Dark Days.

"Then came the Dark Days, the uprising of the districts against the Capitol. Twelve defeated, the thirteenth obliterate. The Treaty of Treason gave us the new laws to guarantee peace and, as our yearly reminder that the Dark Days must never be repeated, it gave us the Hunger Games." -The Hunger Games, p. 18.

The Hunger Games works as an annual reminder to the citizens of Panem of the power of the Capitol. This punishment lasted for 75 years in the form of the Hunger Games and in many other forms of cruelty.

"To make it humiliating as well as torturous, the Capitol requires us to treat the Hunger Games as a festivity, a sporting event pitting every district against the others. The last tribute alive receives a life of ease back home, and their district will be showered with prizes, largely consisting of food. All year, the Capitol will show the winning district gifts of grain and oil and even delicacies like sugar while the rest of us battle with starvation. -The Hunger Games, p. 19.

However, the effect of the Games is not just external. The usual injury is not as bad as witnessing death firsthand. Inner conflicts such as guilt and trauma are born out of the victor as seen in the case of Peeta:

'Peeta, how come I never know when you're having a nightmare?" I say.

"I don't know. I don't think I cry out or thrash around or anything. I just come to, paralyzed with terror," he says.

"You should wake me," I say, thinking about how I can interrupt his sleep two or three times on a bad night. 
About how long it can take to calm me down. "It's not necessary. My nightmares are usually about losing you," he says. "I'm okay once I realize you're here." -Catching Fire, p. 85-86.

The effects of the Hunger Games to the tributes, the family of the tributes, and their respective district are unpleasant, to say the least. This is fundamentally the reason the Capitol and the authoritarian power that sets the government to continuously torment the twelve districts has to be taken down.

\section{Reaping}

The Reaping is part of the Hunger Games ceremony. It is one of the factors the government can exploit its people. It is mostly unforgiving to the poor:

"The reaping system is unfair, with the poor getting the worst of it. You become illegible for the reaping the day you turn twelve."-The Hunger Games, p. 13.

It is even more unfair for the starving family. In particular, Katniss has to sign up for reaping more times in exchange for tesserae. One tessera is worth an insufficient year's supply of grain and oil. Even so, Katniss promises not to add Primrose's name to any Reaping day.

'It's time for the drawing. Effie says as she always does, "Ladies first!" and crosses to the glass ball with the girls' names. She reaches in, digs her hand deep into the ball, and pulls out a small piece of paper... Effie crosses back. to the podium, smoothes the slip of paper, and reads out the name in clear voice. And it's not me. It's Primrose Everdeen." -The Hunger Games, p. 20.

Primrose is called to become the tribute for District twelve. Nonetheless, Katniss offered to take her sister's place. "I volunteer! I volunteer as tribute." - The Hunger Games, p. 22. Upon claiming to be sacrificed in lieu of her sister, the people of District twelve expresses sympathy. No clap is heard, no shout of victory is uttered. Everyone in the District is engrossed with so much hopelessness.

\section{President Snow}

President Snow is the main antagonist in the trilogy. He holds power over the people. Katniss describes President Snow as: "A small, thin man with paper white hair." -The Hunger Games, p. 71. The dialogue below between President Snow and Katniss shows the fragile system of Panem:

"'This of course you don't know. You have no access to information about the mood in other districts. In several of them, however, people viewed your little trick with the berries as an act of defiance, not an act of love. If a girl from District twelve can defy the capitol and walk away unharmed, what is so to stop them from doing the same?" he says. "What is to prevent, say, an uprising?"”

This dialogue solidifies the beginning of President Snow's disapproval of Katniss. During the $74^{\text {th }}$ Hunger Games, Katniss outwitted the Capitol therefore weakening President Snow's control. Moreover, President Snow is not only having disagreements with Katniss. He is also on the warpath with Johanna Mason. President Snow killed her family when she refused to be his prostitute.

'T'm confused because while are they all angry, some are giving us sympathetic pats on the shoulder, and Johanna Mason actually stops to straighten my pearl necklace.

"Make bim pay for it, okay?" she says. I nod, but I don't know what she means." -Catching Fire, p. 250.

President Snow is a detestable figure in the Hunger Games. He appears to be prim and proper with the symbolic rose on his lapel but behind the mask is an authoritarian leader. Snow is a reminder that many controlling leaders will try to maintain the existing state of affairs that serve them.

\section{War}

War is not a new thing in Panem. In the third book, Katniss becomes the Mockingiay, the symbol of the rebellion. The people behind the rebellion uses propaganda materials to deliver their message. The clip conveys the gravity of Katniss' words: 


\section{Famoso, Josephin May Grace A. Slivers of Hope: Women in Dystopian Trilogy}

"President Snow says he is sending us a message? Well, I have one for him. You can torture us and bomb us and burn our districts to the ground, but do you see that?" one of the cameras follows as I point to the planes burning on the roof of the warehouse across from us. The Capitol seal on a wing glows clearly through the flames. "Fire is cathing!" I am shouting now, determined that he will not miss a word. "And if we burn, you burn with us!”-Mockingjay, p. 100.

The clip also shows what the Capitol is doing to the rebels. The clip is broadcasted all over Panem to encourage the citizens of Panem to rise and revolt.

\section{Famine}

Surviving the Games means surviving life. The Capitol keeps the citizens starving by hoarding all the resources of the districts. Even the district that produce agriculture (District eleven) lacks food supply.

"“'Oh," says Rue with a sigh. "I've never had the whole leg to myself before." I'll be she hasn't. I'll bet meat ever bardly comes her way." "Take the other" I say."” Hunger Games, p. 197.

This is also true in other districts. The reason Katniss learned how to hunt to be able to feed meat to her family is because of the exploitation of goods in all of Panem.

"Starvation is not an uncommon fate in District twelve. Who hasn't seen the victims? Older people who can't work. Children from a family with too many to feed." Hunger Games, p. 28

Katniss discerns that the Capitol takes all the share of resources and starves the workers to their deaths. Resulting to more devastating events she has seen in several of the tributes' stories. The abundance in District one is unforgivable:

"And then it hits me. They already have. They have killed her father in those wretched mines. They have sat by as she almost starved to death. They have chosen her as tribute, then made her watch her sister fight to the death in the Games." - Catching Fire, p. 122.

\section{Motivations}

\section{Family}

The female characters are driven to end the cruelty of the Capitol for the safety of their loved ones. Even when Katniss starts to show defiant actions, she is concerned with how her family is going to be affected by her actions.

"Do you think they'll arrest me?" I ask. Doubt it. Be a pain to replace you at this stage," says Haymitch. "What about my family?" I say. "Will they punish them?" "Don't think so. Wouldn't make much sense." -Hunger Games, p. 12.

As Katniss does everything to keep Primrose safe, she is sometimes haunted by the thought of her younger sister being caught in the war.

"Prim. I only need to think of Prim and all my resolve disintegrates. It's my job to protect her. I pull the blanket over my head, and my breatbing is so rapid I use up all the oxygen and begin to choke for air. I can't let the Capitol hurt Prim."-Catching Fire, p. 122.

Primrose, too, supports her sister Katniss by aiding the citizens involved in the war. She works in the hospital to treat the injured. This is according to her the easiest way to show courage despite the dangers of the uprising.

"Where's Prim?" I ask. "Isn't she here?" she replies. "She was supposed to come straight down from the hospital."- Mockingjay, p. 143.

Primrose is a submissive figure in the Hunger Games. She is the one being protected by Katniss throughout the series. Although she is viewed as fragile, she lightens the burden of the rebels in her own little ways.

\section{Friends}

Johanna doesn't have a family to think about since President Snow killed them after she refused his advances. But Johanna thinks of her friends as her family. In a conversation between Katniss and Johanna, they have patched up and became allies:

\footnotetext{
"Johanna grins, and I feel a slight but significant shift in our relationship. I don't know that we're actually friends, but possibly the work allies would be accurate.
} 
That's good. I'm going to need an ally."- Mockingjay, p. 235.

Johanna is another rebel in the Hunger Games series. She has been lay open to many abuses. Nonetheless she still fights for what is right and finds friendship in the most complicated situations like the Hunger Games and during the rebellion.

\section{Goals}

\section{Survive the Games and Live Peacefully}

As for Katniss, her only aspiration is to survive the Games and be back home to District twelve. "Home! Prim and my mother! Gale! Even the thought of Prim's scruffy old cat makes me smile. Soon I will be home." -The Hunger Games, p. 350.

Katniss defines peace as being able to look after her family, especially Primrose. On the day of Reaping, she has to bargain her life for something bigger than peace - the safety of her sister. Besides, she gets to obtain food for her district:

"The last tribute alive receives a life of ease back home, and their district will be showered with prizes, largely consisting of food. All year, the Capitol will show the winning district gifts of grain and oil. And even delicacies like sugar ..."- The Hunger Games, p. 21.

Peace can never be achieved when oppression is still present. Katniss and the rest of the rebels devised a plan to start bring down the Capitol. In relation to Bernardo's study in 2010[2], the help of external and internal agencies make the goals achievable.

\section{Bring the Capitol Down and Change the System}

Johanna's rage for the system continues as she is again called to the arena during the $75^{\text {th }}$ Hunger Games. The tributes this time come from the survivors of previous Games:

"Without hesitation he reads, "On the seventy-fifth anniversary, as a reminder to the rebels that even the strongest among them cannot overcome the power of the Capitol, the male and female tributes will be reaped from the existing pool of victors."-Catching Fire, p. 172.
This fuels Johanna to participate in the uprising. Katniss, too, is part of the rebellion. She becomes the Mockingjay and contributes to change the system:

"An uprising, I think. What an idiot I am. There's an inherent flaw in the plan that both Gale and I were too blind to see. An uprising requires breaking the law, thwarting authority. We've done that all our lives, our families have. - Catching Fire, p. 130.

The women characters have exemplified great strength in spite of the hurdles both external and internal. Their struggles are worth it in the end. In the study of Takani \& Gibni (1995), the resistance worked alongside hope. This tells the readers that political struggles can be challenged. The people killed President Snow as a symbol of destroying the power contained in one man.

Their endurance has paid off. The epilogue suggests that there has been some change in Katniss' world. Katniss once declared that she will never have children because they will only experience the horrors of the Hunger Games. In the epilogue, Katniss' children grow up in a much safer place:

'I make a list in my head of every act of goodness I've seen someone do. It's like a game. Repetitive. Even a little tedious after more than twenty years." - Epilogue $p$. 7-8.

Therefore, Katniss' tenacity changed her world for the better. She becomes the symbol and forerunner for social awakening. Table 2 below indicates the summary of the women characters' struggles, motivations, and goals in the trilogy.

\begin{tabular}{|c|c|c|c|}
\hline Characters & Struggles & Motivation & Goals \\
\hline $\begin{array}{c}\text { Katniss } \\
\text { Everdeen }\end{array}$ & $\begin{array}{l}\text { Hunger } \\
\text { Games, } \\
\text { President } \\
\text { Snow, } \\
\text { War }\end{array}$ & $\begin{array}{l}\text { Family, } \\
\text { Friend }\end{array}$ & $\begin{array}{c}\text { Survive } \\
\text { the } \\
\text { games } \\
\text { and live } \\
\text { peacefully } \\
\text { with her } \\
\text { familiy }\end{array}$ \\
\hline $\begin{array}{l}\text { Primrose } \\
\text { Everdeen }\end{array}$ & $\begin{array}{l}\text { Reaping, } \\
\text { War }\end{array}$ & $\begin{array}{l}\text { Help her } \\
\text { elder sister, } \\
\text { Katniss, to } \\
\text { win the war }\end{array}$ & $\mathrm{X}$ \\
\hline
\end{tabular}




\begin{tabular}{|c|c|c|c|}
\hline & \multicolumn{3}{|c|}{$\begin{array}{l}\text { against the } \\
\text { Capitol }\end{array}$} \\
\hline Rue & $\begin{array}{l}\text { Hunger } \\
\text { Games, } \\
\text { Famine }\end{array}$ & $\mathrm{X}$ & $\mathrm{X}$ \\
\hline Johanna Mason & $\begin{array}{l}\text { Hunger } \\
\text { Games, } \\
\text { President } \\
\text { Snow, } \\
\text { War }\end{array}$ & Friends & $\begin{array}{l}\text { Being the } \\
\text { Capitol } \\
\text { down and } \\
\text { change } \\
\text { the } \\
\text { system }\end{array}$ \\
\hline
\end{tabular}

Table 2. Struggles, Motivations, and Goals

\section{CONCLUSION}

In a nutshell, all stages of Feminism according to Showalter's theory[16] are present in the Hunger Games Trilogy. Nonetheless, not all stages are applicable to the women characters in the study.

Based on the analysis, women characters were slivers of light amidst the chaos. The main character, Katniss Everdeen, saw the collapse of the ruling government in power as she accepted being the Mockingjay, the symbol of the revolution. On the subject of being the Monckingjay, Katniss' feminine traits allows her to break free from the past and change her society[8]. Another woman character to exemplify such a noble act was Johanna Mason who became part of the rebellion and survived the war against the unjust ruling of the Capitol. Conversely, characters who have not undergone the second and third stages, such as Primrose Everdeen and Rue were susceptible to be killed by the system. Yet the revolution was not possible without their valuable contributions. Therefore, women characters play pivotal roles in society. The women characters recognized their power to accelerate societal advancement or change the system that does not serve everyone in Panem.

Notably, the struggles of the women characters exist in both Panem and the real world. The author of the trilogy used a literary technique to relate the problems experienced by Katniss and other women characters in order to recognize the same problems in our world. In line with Thaler[19], fiction is helpful to enhance our awareness of the world we live in today and to hope for a better tomorrow.
Consistently, literary texts are associated with meanings thereby exposing an existing struggle and encouraging readers to think and make appropriate changes that impact their future.

\section{REFERENCES}

[1] Beltran, M. (2021, April 26). How a Community Pantry Sparked Movement of Mutual Aid in the Philippines. The News Lens International Edition.

https://international.thenewslens.com/article $\angle 149976$

[2] Bernardo, A. B. (2010). Extending hope theory: Internal and external locus of trait hope. Personality and Individual Differences, 49(8), 944949.

https://doi.org/10.1016/i.paid.2010.07.036

[3] Coleman, R., \& Ferreday, D. (2010). Introduction: Hope and Feminist Theory. Journal for Cultural Research, 14(4), 313-321. https://doi.org/10.1080/14797581003765283

[4] Collins, S. (2008). The Hunger Games (Book 1) (Reprint ed.). Scholastic Press.

[5] Collins, S. (2009). Catching Fire (Hunger Games2) (Reprint ed.). Scholastic Press.

[6] Collins, S. (2010). Mockingjay (Hunger Games) (1st ed.). Scholastic Press.

[7] Ertsgaard, G. (2021). Peeta's Virtue in the Hunger Games Trilogy. Journal of Feminist Scholarship, 18(18). https://doi.org/10.23860/jfs.2021.18.07

[8] Hansen, K. S. (2015). The Metamorphosis of Katniss Everdeen: The Hunger Games, Myth, and Femininity. Children's Literature Association Quarterly, 40(2), 161-178. https://doi.org/10.1353/chq.2015.0020

[9] Kang jun-young, et al. (2017). The DeChinization Policy of Tsai Ing-wen and Influence on Cross-Straight Relations. (54), 389-412.

https://doi.org/10.35221/tamla.2017..54.013


[10]Klapisch, C. (1995). Feminine identity and mass consumption: A semiotic analysis of feminine products packaging. Semiotica, 104(1-2). https://doi.org/10.1515/semi.1995.104.1-2.99

[11]Kolb, D. (2021). Adaptive leadership: The case of Jacinda Ardern and New Zealand. Academia Letters, 1-4. https://doi.org/10.20935/al557

[12]Hawthorne, N. (1992). Scarlet Letter (Wordsworth Classics) (Reprint ed.). Wordsworth Editions Ltd.

[13]Nehere, K. (2016). The Feminist Views: A Review. Feminist Research, 1(1), 3-20. https://doi.org/10.21523/gcj2.16010101

[14]Oliver, K. (2014). Ambiguity, Ambivalence and Extravagance in The Hunger Games. Humanities, 3(4), 675-686. https://doi.org/10.3390/h3040675

[15]Rigaud, S. (2013). https://www.app.pan.pl/article/item/app201 20056.html. Acta Palaeontologica Polonica.

Published. https://doi.org/10.4202/app.2012.0056

[16]Showalter, E. (1999). Elaine Showalter. The Lancet, $\quad 354(9176), \quad 438$. https://doi.org/10.1016/s0140$\underline{6736(05) 75868-2}$

[17]Simmons, A. M. (2012). Class on Fire: Using the Hunger Games Trilogy to Encourage Social Action. Journal of Adolescent \& Adult Literacy, 56(1), 22-34. https://doi.org/10.1002/jaal.00099

[18]Smith, N. (2005). Hope and Critical Theory. Critical Horizons, 6(1), 45-61. https://doi.org/10.1163/15685160577500952 $\underline{8}$

[19]Thaler, M. (2017). Hope Abjuring Hope: On the Place of Utopia in Realist Political Theory. Political Theory, 46(5), 671-697. https://doi.org/10.1177/0090591717740324 